\title{
(2) Spontaneously conceived 17-week heterotopic OPEN ACCESS pregnancy: a challenging and unusual diagnosis
}

\author{
Sara de Oliveira, Michal Yaron, Patrick Dällenbach
}

Division of Gynecology, Department of Pediatrics, Obstetrics and Gynecology, Hopitaux Universitaires de Geneve, Geneva, Switzerland

\section{Correspondence to} Dr Sara de Oliveira; sara.s.deoliveira@hcuge.ch

Accepted 15 February 2021

\begin{abstract}
SUMMARY
A 37-year-old woman, gravida 2 para 1, arrived in our emergency clinic at 16 2/7 weeks of a spontaneously conceived pregnancy for abdominal pain. She was on oral antibiotics for 2 days to treat a suspected urinary tract infection with no improvement. Blood tests, abdominal ultrasound and intrauterine fetus were all normal. She left our emergency unit with laxatives. Four days later, she returned to our clinic with severe abdominal pain. We repeated abdominal and foetal ultrasonography and identified a left para-uterine $7 \times 5 \mathrm{~cm}$ mass. As adnexal torsion was suspected, we performed an emergency laparoscopy. At laparoscopy, we found a left haematosalpinx and realised a left salpingectomy. Histology confirmed the presence of a heterotopic pregnancy (HP). This case illustrates the importance of exploring the adnexa in a gravid woman presenting with abdominal pain in the first and early second trimesters. Although rare, excluding a HP may prevent a life-threatening haemorrhage.
\end{abstract}

\section{BACKGROUND}

First described in 1761 as an autopsy finding, ${ }^{1}$ heterotopic pregnancy (HP) is defined as concomitant pregnancies developing at two different implantation sites. Most often, an intrauterine pregnancy is seen with a tubal ectopic pregnancy. However, other implantations sites have been described. ${ }^{2}$ Long considered to be a rare event accounting for $1 / 30000$ spontaneous pregnancies, ${ }^{3}$ the incidence of HP has increased with the use of assisted reproductive procedures, reaching rates of $1 / 100$ in this population. ${ }^{4}$ We report a case of spontaneous HP diagnosed at 17 weeks of amenorrhoea, treated by laparoscopy and followed by the normal development of the intrauterine pregnancy.

\section{CASE PRESENTATION}

A 37-years-old pregnant woman, gravida 2 para 1 , consulted our emergency clinic at 16 2/7 weeks of amenorrhoea for abdominal pain, which started 2 days before. Her pregnancy was spontaneously conceived. She was initially treated with cefuroxime prescribed by her gynaecologist who suspected cystitis, but failed to improve. In our service, she had problem of acute left pelvic pain irradiating to the back and left thigh. The patient denied having had vaginal bleeding, urinary or digestive symptoms. She did not have any relevant medical history, except for a normal vaginal delivery 16 months earlier.

On clinical examination, her heart rate was 84 beats/min, blood pressure was 100/55 mm Hg with a temperature of $37.3^{\circ} \mathrm{C}$. The abdominal wall was tender without guarding nor rebound. On pelvic examination, there was a small quantity of blood in the vagina, and no adnexal mass was palpable on bimanual examination. The uterus was measured at $17 \mathrm{~cm}$, as expected for the gestational age.

\section{INVESTIGATIONS}

In order to exclude a urinary tract infection, we performed a blood analysis and a urine dipstick/ culture. Both examinations were normal (red blood cell count of $114 \mathrm{~g} / \mathrm{L}$, white cell count of $6.6 \times 10^{9} / \mathrm{L}, \mathrm{C}$ reactive protein $12.7 \mathrm{mg} / \mathrm{L}$, creatinine $47 \mu \mathrm{mol} / \mathrm{L})$. Nephrolithiasis and appendicitis were ruled out by an abdominal ultrasonography. Obstetrical ultrasonography showed a viable fetus corresponding to the weeks of amenorrhoea. However, the adnexa were not described initially. The patient left our emergency unit with laxatives for suspected constipation.

Four days later, she returned to our emergency unit with severe abdominal pain. At clinical examination, she had signs of peritoneal irritation. We repeated laboratory exams. Blood test revealed a decrease in the haemoglobin value $(101 \mathrm{~g} / \mathrm{L}$ vs $114 \mathrm{~g} / \mathrm{L})$. White cell blood count was stable. Ultrasonography showed an ongoing intrauterine pregnancy, but also a poorly vascularised left parauterine $7 \times 5 \mathrm{~cm}$ mass (figure 1 ) sensitive to probe passage.

\section{DIFFERENTIAL DIAGNOSIS}

Based on the ultrasonography, we suspected a possible adnexal torsion or haemorrhagic rupture of an ovarian cyst. Non-gynaecological causes such as appendicitis, constipation or urinary tract disorders (infection, lithiasis) were less likely. There was no visible myoma to suspect necrobiosis.

\section{TREATMENT}

To exclude a potential life-threatening condition, we performed an emergency laparoscopy. To avoid haemodynamic and respiratory adverse effects on placental blood flow, ${ }^{5}$ we insufflated the gaz $\left(\mathrm{CO}_{2}\right)$ in the left hypochondrium using low pneumoperitoneum pressure (less than $12 \mathrm{~mm} \mathrm{Hg}$ ). The intraoperative status revealed a $100 \mathrm{~mL}$ haemoperitoneum and a complex left adnexal mass of $5 \times 7 \mathrm{~cm}$ (figures 2 and 3) adherent to the uterus and surrounded by clots. After careful adhesiolysis, we performed a left salpingectomy for suspicion of tubal HP.

\section{OUTCOME AND FOLLOW-UP}

Histology confirmed the presence of chorionic villus. The postoperative course was uneventful. 


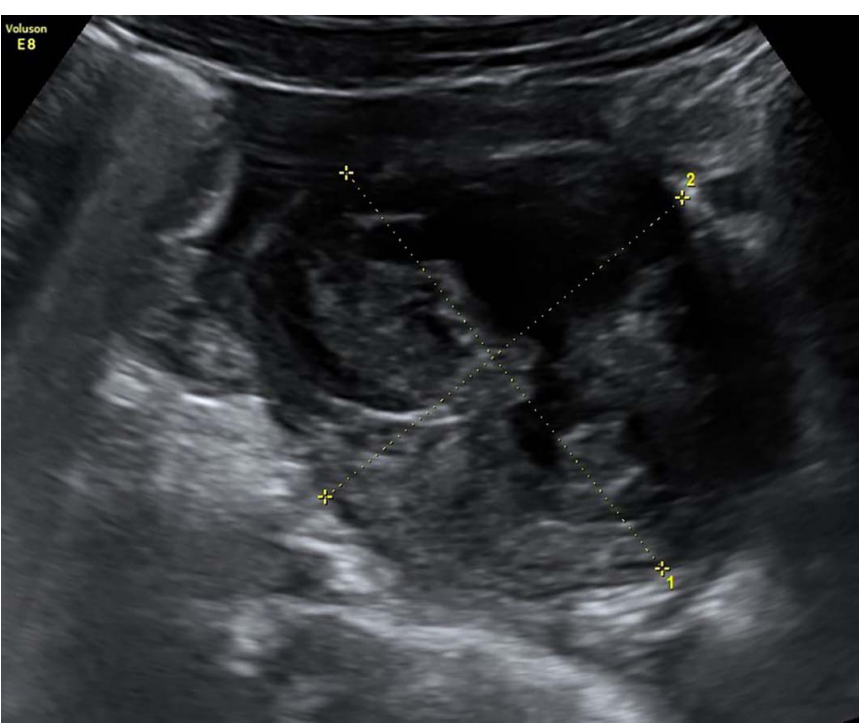

Figure 1 Left para-uterine mass $7 \times 5 \mathrm{~cm}$.

Two days after surgery, ultrasound confirmed the well-being of the intrauterine fetus. The patient was discharged on the third postoperative day.

Later on, at $403 / 7$ weeks, she delivered a healthy live baby by caesarean after induction of labour for post-term pregnancy had failed.

\section{DISCUSSION}

Most publications report HP in the second trimester after assisted reproductive therapy. This condition occurs very rarely in spontaneous pregnancy. ${ }^{6-8}$. In our case report, the failure to identify this condition and evaluate the adnexa during initial care could have resulted in a disastrous outcome.

Apart from assisted reproductive procedures, ${ }^{9}$ risk factors for $\mathrm{HP}$ are pelvic inflammatory disease, history of ectopic pregnancy and/or pelvic surgery. ${ }^{2}$ In a systematic review, ${ }^{2} \mathrm{HP}$ occurred in $29 \%$ of women without any risk factors, as was the case in our patient, resulting in delayed diagnosis and treatment. Symptoms such as abdominal pain, vaginal bleeding or signs of haemodynamic instability can be present, but are not always the case. ${ }^{2}$ In

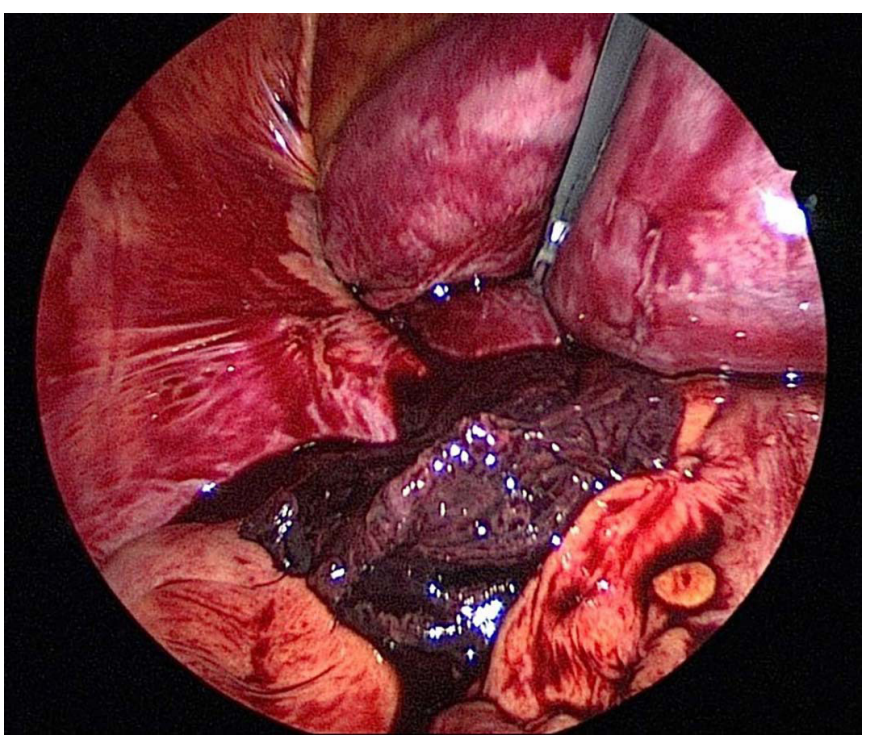

Figure 2 Left adnexal mass surrounded by a haematoma.

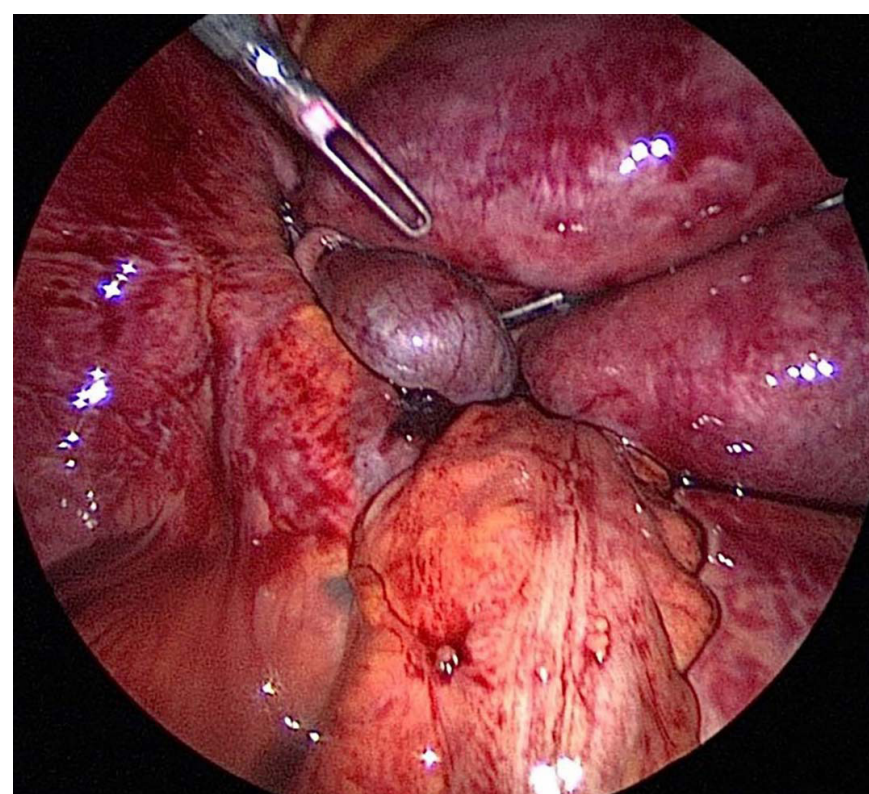

Figure 3 Left tubal heterotopic pregnancy.

a retrospective study, $32 \%$ of patients remained asymptomatic at diagnosis. ${ }^{10}$

Serum beta-hCG assay is not useful in the diagnosis of $\mathrm{HP}^{9}{ }^{9}$ Transvaginal ultrasonography is a diagnostic tool with a sensitivity of $92 \%$ and specificity of $100 \%$ in a population where HP is actively sought. ${ }^{9}$ The sensitivity rate is drastically reduced to $66 \%$, if HP was not previously suspected. ${ }^{2}$

It is therefore important to exclude an HP in every gravid woman presenting with abdominal pain in the first and early second trimester. Accurate diagnosis is of utmost importance as it promotes adequate treatment to prevent complications of tubal rupture. This could not only lead to life-threatening haemorrhage, but also to spontaneous abortion of the intrauterine pregnancy, reported in $12 \%-26 \%$ of $\mathrm{HP}^{2}{ }^{10}$

Therapeutic options are most often surgical, either by laparoscopy or by laparotomy. According to the Talbot et al review, ${ }^{2}$ $33 \%$ of patients are haemodynamically unstable, making laparotomy mandatory. If the patient is haemodynamically stable, the laparoscopic approach is preferred if performed by an experienced surgeon. ${ }^{11}$ During surgery, the ectopic pregnancy is removed while efforts are made to preserve the intrauterine pregnancy. For laparoscopy, use of low pneumoperitoneum pressure is required, after needle insertion distant from the gravid uterus. ${ }^{5}$ Medical treatment is preferred in cases of interstitial, ${ }^{12}$ cervical $^{13}$ and caesarean scar heterotopic pregnancy. ${ }^{14}$ In these situations, drugs such as potassium chloride, methotrexate or hyperosmolar glucose are administered under ultrasonographic visualisation into the extrauterine gestational sac.

In conclusion, HP is a diagnostic and therapeutic challenge. Adequate and timely approach can not only prevent a lifethreatening tubal rupture, but also miscarriage of a concomitant intrauterine pregnancy. It is therefore important to consider this diagnosis in every gravid woman presenting with abdominal pain in the first half of pregnancy. Evaluation of the adnexa using abdominal and transvaginal ultrasonography should always be performed.

Contributors SdO: authorship, acquisition of data, review of the literature, interpretation of the case. PD: authorship, acquisition of data, interpretation of the case. MY: authorship, review of the case. 


\section{Learning points}

- Symptoms of chronic heterotopic pregnancy may be mild and mimic other abdominal pathologies thus delaying diagnosis.

- Heterotopic ectopic pregnancy should be considered in the differential diagnosis of pregnant women with abdominal pain.

- In order to exclude this condition, evaluation of the adnexa using abdominal and transvaginal ultrasonography should always be performed during the first half of pregnancy.

Funding The authors have not declared a specific grant for this research from any funding agency in the public, commercial or not-for-profit sectors.

Competing interests None declared.

Patient consent for publication Not required.

Provenance and peer review Not commissioned; externally peer reviewed.

Open access This is an open access article distributed in accordance with the Creative Commons Attribution Non Commercial (CC BY-NC 4.0) license, which permits others to distribute, remix, adapt, build upon this work non-commercially, and license their derivative works on different terms, provided the original work is properly cited and the use is non-commercial. See: http://creativecommons.org/ licenses/by-nc/4.0/.

\section{REFERENCES}

1 Duvernay GJ. Oeuvres anatomiques. Paris: Joubert, 1761.
2 Talbot K, Simpson R, Price N, et al. Heterotopic pregnancy. J Obstet Gynaecol 2011:31:7-12.

3 DeVOE RW, PRATT JH. Simultaneous intrauterine and extrauterine pregnancy. Am J Obstet Gynecol 1948:56:1119-26.

4 Tal J, Haddad S, Gordon N, et al. Heterotopic pregnancy after ovulation induction and assisted reproductive technologies: a literature review from 1971 to 1993. Fertil Steril 1996;66:1-12

5 Pearl J, Price R, Richardson W, et al. Guidelines for diagnosis, treatment, and use of laparoscopy for surgical problems during pregnancy. Surg Endosc 2011;25:3479-92.

6 Hassiakos D, Bakas P, Pistofidis G, et al. Heterotopic pregnancy at 16 weeks of gestation after in-vitro fertilization and embryo transfer. Arch Gynecol Obstet 2002;266:124-5.

7 Lewin A, Simon A, Rabinowitz R, et al. Second-trimester heterotopic pregnancy after in vitro fertilization and embryo transfer-a case report and review of the literature. Int J Fertil 1991:36:227-30.

8 Shojai R, Chaumoitre K, Chau C, et al. Advanced combined abdominal and intrauterine pregnancy: a case report. Fetal Diagn Ther 2007;22:128-30.

9 Li XH, Ouyang Y, Lu GX. Value of transvaginal sonography in diagnosing heterotopic pregnancy after in-vitro fertilization with embryo transfer. Ultrasound Obstet Gynecol 2013;41:563-9.

10 Yu Y, Xu W, Xie Z, et al. Management and outcome of 25 heterotopic pregnancies in Zhejiang, China. Eur J Obstet Gynecol Reprod Biol 2014;180:157-61.

11 Eom JM, Choi JS, Ko JH, et al. Surgical and obstetric outcomes of laparoscopic management for women with heterotopic pregnancy. J Obstet Gynaecol Res 2013;39:1580-6

12 Ozgur K, Isikoglu M. Cornual heterotopic pregnancy: conservative treatment with transvaginal embryo reduction. Arch Gynecol Obstet 2005;271:73-5.

13 Suzuki M, Itakura A, Fukui R, et al. Successful treatment of a heterotopic cervical pregnancy and twin gestation by sonographically guided instillation of hyperosmolar glucose. Acta Obstet Gynecol Scand 2007:86:381-3.

14 Taşkin S, Taşkin EA, Ciftçi TT. Heterotopic cesarean scar pregnancy: how should it be managed? Obstet Gynecol Surv 2009;64:690-5.

Copyright 2021 BMJ Publishing Group. All rights reserved. For permission to reuse any of this content visit https://www.bmj.com/company/products-services/rights-and-licensing/permissions/

BMJ Case Report Fellows may re-use this article for personal use and teaching without any further permission.

Become a Fellow of BMJ Case Reports today and you can:

- Submit as many cases as you like

- Enjoy fast sympathetic peer review and rapid publication of accepted articles

- Access all the published articles

- Re-use any of the published material for personal use and teaching without further permission

Customer Service

If you have any further queries about your subscription, please contact our customer services team on +44 (0) 2071111105 or via email at support@bmj.com.

Visit casereports.bmj.com for more articles like this and to become a Fellow 